\title{
Building evaluation using two components of acceleration time histories causes by shallow crustal fault earthquakes with maximum magnitude $7 \mathrm{Mw}$
}

\author{
Windu Partono ${ }^{1, *}$, Masyhur Irsyam ${ }^{2}$, Indrastono Dwi Atmanto ${ }^{1}$, Andi Retno Ari Setiaji ${ }^{1}$, \\ Sigit Purnomo ${ }^{1}$, and Robby Yanuar Setiawan ${ }^{1}$ \\ ${ }^{1}$ Civil Engineering Department, Diponegoro University, 50275 Semarang, Indonesia \\ ${ }^{2}$ Civil Engineering Department, Bandung Institute of Technology, 40132 Bandung, Indonesia
}

\begin{abstract}
Spectral acceleration and acceleration time histories are the two seismic loads generally used for dynamic analysis of a building. The structural design of buildings is implemented using spectral acceleration at the ground surface obtained from the national seismic code. However, acceleration time histories are developed from specific earthquake events and implemented for building evaluation. This paper presents building evaluations of three existing buildings located in Semarang with heights of at least $40 \mathrm{~m}$. The buildings were built on three different soil types, that is, hard, medium and soft soils. The evaluation was performed by conducting two component north-south and east-west directions of acceleration time histories modified from Semarang fault earthquake scenarios having a magnitude of $7 \mathrm{Mw}$ and maximum epicentre distance $15 \mathrm{Km}$. Due to incomplete data on Semarang fault earthquakes, the acceleration time histories incorporated herein were collected from worldwide earthquake data bases and modified using response spectral matching and seismic propagation analysis. Stability analyses in terms of structural deformation and drift ratio were carried out for the three buildings. The results show that all three buildings have the capability to resists earthquakes up to a maximum magnitude of $6.5 \mathrm{Mw}$ with an epicentre distance of over $5 \mathrm{Km}$.
\end{abstract}

\section{Introduction}

Stability analysis from earthquake event scenarios is one of the important methods of evaluating the stability of the structure. The analysis is performed by taking acceleration time history data generated from earthquake events as the input earthquake load on the structure. The objective of this analysis is to obtain the resistance of the structure when subjected to an earthquake in terms of magnitude and distance. The stability of a structure is evaluated with respect to the deformation and internal drift ratio caused by earthquake forces and response spectral acceleration models. Response spectral acceleration data are

* Corresponding author: windu_bapake_dila@yahoo.com 
obtained from national seismic codes. It is difficult to obtain seismic load data or acceleration time histories from a specific earthquake event. Civil engineers will only use seismic data from strong earthquake events for structural design and evaluations. Acceleration time histories are one of the important seismic load models that should be taken into account when evaluating the stability and stiffness of buildings.

Inter-story drift and lateral stability evaluation of tall buildings in Semarang has already been carried out for eight buildings by incorporating single-direction acceleration time histories [1]. The analysis was performed using acceleration time histories developed from Lasem fault earthquake scenarios (strike slip mechanism) with a maximum magnitude of 7 $\mathrm{Mw}$ and a maximum epicentre distance of $15 \mathrm{Km}$. Out of eight buildings, three are unable to resist earthquake forces caused by Lasem fault earthquake scenarios with a magnitude greater than $6.5 \mathrm{Mw}$ and an epicentre distance of less than $10 \mathrm{Km}$. This paper presents a similar analysis for three buildings (hospital, hotel, and university buildings) with respect to two components or directions (north-south (NS) and east-west (EW)) of Semarang fault earthquake scenarios.

\section{Geotechnical and geological informations}

Site classification of Semarang in terms of shear wave velocities $\left(\mathrm{V}_{\mathrm{s} 30}\right)$ was carried out by interpreting the results of boring investigations with a minimum depth of $30 \mathrm{~m}[2,3]$. The $\mathrm{V}_{\mathrm{s} 30}$ values of the buildings were estimated following the method proposed by [4]. To perform the $\mathrm{V}_{\mathrm{s} 30}$ calculation, all N-SPT (Standard Penetration Test) data for the top 30metre soil layers of each boring location were first modified into shear wave velocity (Vs) values using three empirical correlation equations proposed by [5, 6, and 7]. The site soil class of each building location may be predicted following the method proposed by [4] using the $\mathrm{V}_{\mathrm{s} 30}$ value.

Surface acceleration time histories used for structural analysis were developed using Site Specific Analysis (SSA). Important data needed for SSA are the acceleration time histories at bedrock elevation, the bedrock elevation and the soil profile from bedrock elevation to surface. Soil profile data for SSA were collected from boring investigations with a minimum depth of $30 \mathrm{~m}$. Data collected from boring and laboratory investigations are N-SPT, soil density, type of soil and the thickness of each soil layer. Bedrock elevation was predicted by performing a Single Station Feedback Seismometer test using ambient noise vibrations [8]. Table 1 shows the building dimension, the geotechnical data in terms of site class, the predicted bedrock elevation and the distance from buildings to Semarang fault trace. SC, SD and SE stand for hard, medium and soft soil class, respectively.

Table 1. Building and geotechnical data.

\begin{tabular}{|c|c|c|c|c|c|}
\hline $\begin{array}{c}\text { Building } \\
\text { Number }\end{array}$ & $\begin{array}{c}\text { Dimension } \\
\text { Plans (m) }\end{array}$ & $\begin{array}{c}\text { Building } \\
\text { Height }(\mathrm{m})\end{array}$ & $\begin{array}{c}\text { Site } \\
\text { Class }\end{array}$ & $\begin{array}{c}\text { Depth of } \\
\text { Bedrock }(\mathrm{m})\end{array}$ & $\begin{array}{c}\text { Distance } \\
(\mathrm{Km})\end{array}$ \\
\hline B1 (Hospital) & $22 \times 78$ & 48.73 & SE & 165 & 3.31 \\
\hline B2 (Hotel) & $28.8 \times 19.75$ & 41.2 & SC & 40 & 0.65 \\
\hline $\begin{array}{c}\text { B3 } \\
\text { (University } \\
\text { Building) }\end{array}$ & $40.75 \times 16.2$ & 43.2 & SD & 60 & 4.98 \\
\hline
\end{tabular}




\section{Development of acceleration time histories}

New Indonesian seismic hazard maps were developed in 2017 by National Center for Earthquake Studies [9]. The Semarang fault is an important earthquake source which may produce seismic waves for Semarang. Based on Indonesia's seismic hazard maps 2017, the Semarang fault has a reverse slip mechanism. Table 2 shows the seismic parameters of the Semarang fault. It includes the seismic magnitude that should be taken into account in seismic hazard analysis and mitigation for the whole area of Semarang.

Table 2. Seismic parameters of Semarang fault [9].

\begin{tabular}{|c|c|c|c|c|c|}
\hline $\begin{array}{c}\text { Structure } \\
\text { Name }\end{array}$ & Segment & $\begin{array}{c}\text { Slip Rate } \\
(\mathrm{mm} / \text { year })\end{array}$ & Mechanism & $\begin{array}{c}\text { Dip } \\
\text { (degree) }\end{array}$ & $\begin{array}{c}\text { Magnitude } \\
\text { (Mw) }\end{array}$ \\
\hline $\begin{array}{c}\text { Baribis- } \\
\text { Kendeng Fold } \\
\text { Thrust Zone }\end{array}$ & Semarang & 0.1 & Reverse Slip & 45 & 6.5 \\
\hline
\end{tabular}

Since there are no data for Semarang fault earthquakes with a magnitude of $6.5 \mathrm{Mw}$, acceleration time histories incorporated in this research were obtained from the ground motion in worldwide databases of strong earthquakes. In this research, four acceleration time histories representing Semarang fault earthquake events were obtained from the Pacific Earthquake Engineering Research (PEER) NGA West-2 Database. All the acceleration time histories incorporated in this study have similar seismic mechanisms, magnitudes, and epicentre distances to the Semarang fault earthquake scenarios. These acceleration time histories also depend on the position of each building in relation to the Semarang fault trace. Table 3 shows the acceleration time histories used in the analysis. Acceleration time histories collected from the PEER NGA West-2 database should be modified to match the time histories of Semarang fault earthquakes using response spectral matching analysis. The modified acceleration time histories were then propagated to surface elevation to obtain surface acceleration time histories using SSA [10-12]. Response spectral matching and SSA for all three buildings were implemented using the same steps as were used in [1] and Nera Software [13].

\section{Structures analysis}

The structural analysis is carried out on a 3D structural model to get the story drift and drift ratio due to load combinations of live load, dead load and seismic force. Seismic force was implemented by conducting two model earthquake forces, namely two directions ( $\mathrm{X}$ and $\mathrm{Y}$ directions) of surface spectral acceleration and two components of surface acceleration time histories. The surface spectral acceleration used in the structural analysis was implemented from the surface spectral acceleration developed based on SNI-03-1726-2012 [4]. The analysis of the buildings was also performed using two components ( $\mathrm{N}-\mathrm{S}$ and $\mathrm{E}-\mathrm{W}$ directions) of acceleration time histories. Figures 1(a) and 1(b) show two components of the acceleration time histories (N-S and E-W directions) of the Iwate Japan earthquake with a magnitude of $6.9 \mathrm{Mw}$ and an epicentre distance of $7.82 \mathrm{Km}$. The story drift and internal drift ratio calculated based on two different methods were then compared to evaluate the resistance capability of the buildings against earthquake forces. If the drift ratio calculated using surface spectral acceleration is greater than the drift ratio calculated using surface acceleration time histories, it means that the building has the capability to resist seismic waves from earthquakes of a specific magnitude and epicentre distance or the buildings is predicted is strong enough to resist an earthquake with a specific scenario. 
Table 3. Acceleration time histories for Semarang fault earthquake scenarios.

\begin{tabular}{|c|c|c|}
\hline $\begin{array}{c}\text { Earthquake } \\
\text { Events }\end{array}$ & $\begin{array}{c}\text { Station (m) and Epicentre Distance } \\
(\mathrm{Km})\end{array}$ & $\begin{array}{c}\text { Magnitude } \\
(\mathrm{Mw})\end{array}$ \\
\hline $\begin{array}{c}\text { Chuetsu-oki } \\
\text { Japan }\end{array}$ & $\begin{array}{c}\text { Nagaoka (3.98) and Joetsu Kakizakiku } \\
\text { Kakizaki (9.43) }\end{array}$ & 6.8 \\
\hline Iwate, Japan & $\begin{array}{c}\text { IWTH24 (3.1), Mizusawaku Interior O } \\
\text { Ganecho (7.82) and IWTH24 (11.68) }\end{array}$ & 6.9 \\
\hline San Simeon, CA & $\begin{array}{c}\text { Cambria - Hwy 1 Caltrans Bridge } \\
\text { (5.07) and Templeton - one-story } \\
\text { hospital (6.97) }\end{array}$ & 6.52 \\
\hline $\begin{array}{c}\text { Northridge-02, } \\
\text { California }\end{array}$ & $\begin{array}{c}\text { Newhall - Fire Sta (7.36) and Pacoima } \\
\text { Kagel Canyon (6.61) }\end{array}$ & 6.05 \\
\hline
\end{tabular}
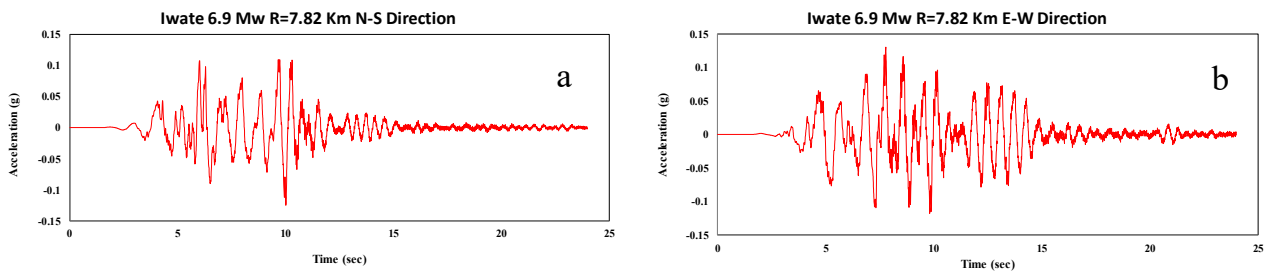

Fig. 1. Two-component surface acceleration time histories: N-S (a) and E-W (b) of Iwate earthquake with a magnitude of $6.9 \mathrm{Mw}$ and epicentre distance of $7.82 \mathrm{Km}$.

Figure 2(a) shows the comparison of response spectral acceleration calculated for building B1 based on SNI-03-1726-2012 and 4 (four) surface spectral acceleration of the Chuetsu-oki $9.43 \mathrm{Km}$, Iwate 7.82 Km, San Simeon 6.97 Km, and Northridge-02 6.61 Km earthquake events. Two-component seismic response spectral developed from Iwate earthquake acceleration time histories with a magnitude of $6.9 \mathrm{Mw}$ and an epicentre distance of $7.82 \mathrm{Km}$ are greater than the response spectral of SNI-03-1726-2012. Figure 2(b) shows the internal drift ratio of building B1 using four acceleration time histories and SNI-03-1726-2012 spectral acceleration. As can be seen in Figure 2(b), the drift ratio calculated using the two-component acceleration time histories of Iwate earthquake 7.82 $\mathrm{Km}$ is greater than the internal drift ratio calculated using SNI-03-1726-2012 spectral acceleration. These two figures show good correlation between spectral acceleration and acceleration time histories in producing the internal drift ratio of the building.
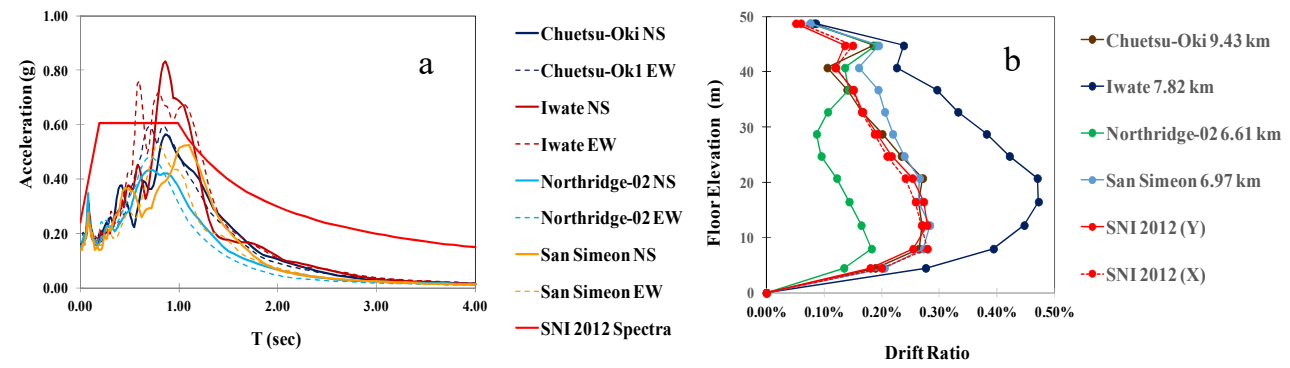

Fig. 2. Comparison of spectral acceleration calculated from SNI-03-1726-2012 and two-component acceleration time histories of four earthquake events (a) and drift ratio (b) of building B1. 


\section{Results and discussion}

The inter-story drift of the three buildings, calculated using acceleration time histories, were evaluated based on a combination of magnitude and epicentre distance. Based on Figures 2(a) and 2(b), a modified analysis was performed for building B1 using the Iwate earthquake with an epicentre distance of $11.68 \mathrm{Km}$. Figure 3(a) shows the comparison of all spectral acceleration for building B1 calculated using SNI-03-1726-2012 and calculated from two-component acceleration time histories of the Chuetsu-oki $9.43 \mathrm{Km}$, Iwate 11.68 Km, San Simeon $6.97 \mathrm{Km}$, and Northridge-02 6.61 Km earthquake events. It seems that for building B1, all the spectral acceleration values calculated from the acceleration time histories are less than the SNI-03-1726-2012 spectral acceleration. It can be seen in Figure 3 (b) that internal drift ratio curves calculated from all acceleration time histories are less than or approximately equal to the internal drift ratio calculated using the SNI spectral acceleration. Maximum drift ratio curves obtained from acceleration time histories were measured at building elevations of 10 to $15 \mathrm{~m}$. Although the drift ratio calculated from acceleration time histories at $25 \mathrm{~m}$ floor elevation of building B1 is greater than the drift ratio from the spectral acceleration, the amount remained less than the maximum drift ratio at 10 to $15 \mathrm{~m}$ floor elevation of building B1. Building B1 is strong enough to resist the Iwate earthquake with a minimum epicentre distance of $11.68 \mathrm{Km}$.

Figure 4(a) shows all drift ratios for building B2 calculated using the Chuetsu-oki 9.43 Km, Iwate $7.82 \mathrm{Km}$, San Simeon $6.97 \mathrm{Km}$, and Northridge-02 6.61 Km earthquake events. Figure 4(b) shows all drift ratios for building B3 calculated using the Chuetsu-oki $9.43 \mathrm{Km}$, Iwate $11.68 \mathrm{Km}$, San Simeon $6.97 \mathrm{Km}$, and Northridge-02 6.61 Km earthquake events. Building B2 and B3 are strong enough to resist an earthquake having a magnitude of less than $6.9 \mathrm{Mw}$ and an epicentre distance greater than $6.61 \mathrm{Km}$.
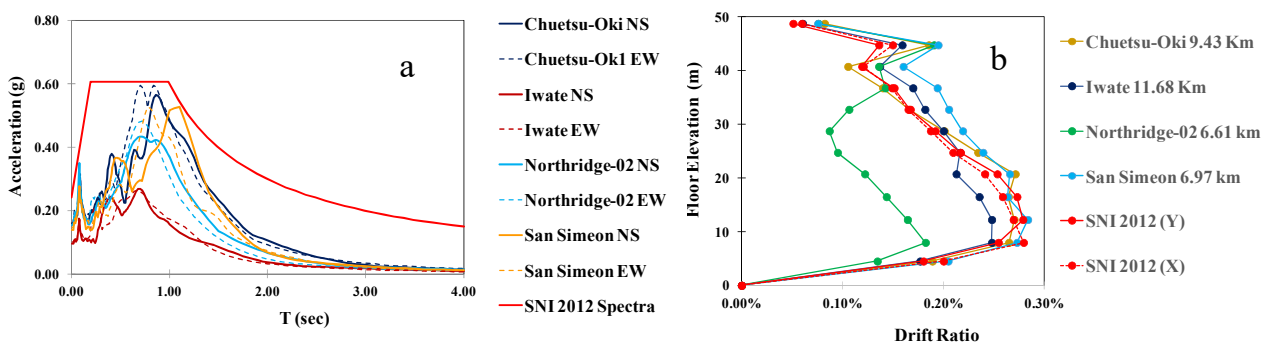

Fig. 3. Comparison of SNI-03-1726-2012 spectral acceleration and the modified spectral acceleration (a) and drift ratio (b) for building B1 when subjected to four acceleration time histories from past strong earthquakes and spectral acceleration based on SNI-03-1726-2012.
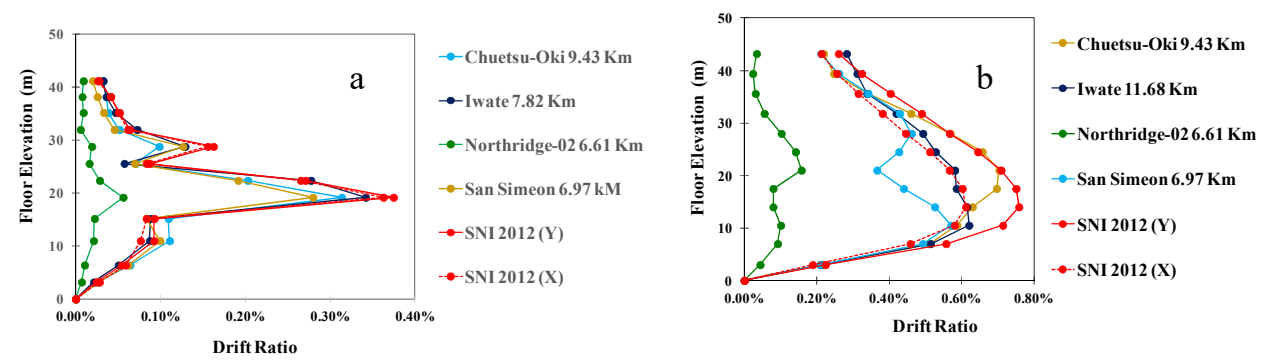

Fig. 4. Drift ratio for building B2 (a) and B3 (b) when subjected to four acceleration time histories from past strong earthquakes and spectral acceleration based on SNI-03-1726-2012. 


\section{Conclusions}

The resistance of a building in terms of its internal drift ratio when subjected to two components of acceleration time histories may be predicted by comparing the spectral acceleration based on SNI-03-1726-2012 and two components of spectral acceleration time histories at the ground surface. The building has adequate resistance against earthquake when its spectral acceleration based on SNI-03-1726-2012 is greater than the other two components of the spectral acceleration time histories.

Based on the building evaluation carried out for the buildings B1, B2, and B3, it seems that buildings B1 and B3 have the resistance capability to sustain earthquakes with a magnitude of $6 \mathrm{Mw}$ to $6.8 \mathrm{Mw}$ and a minimum epicentre distance of $5 \mathrm{Km}$. Buildings $\mathrm{B} 1$ and B3 also have a resistance capability to resist earthquakes with a magnitude of $6.9 \mathrm{Mw}$ and minimum epicentre distance of $10 \mathrm{Km}$. Building B2 is strong enough to resist earthquakes with a magnitude of $6 \mathrm{Mw}$ to $6.9 \mathrm{Mw}$ and a minimum epicentre distance of 5 $\mathrm{Km}$.

This research was financially supported by The Faculty of Engineering, Diponegoro University, Indonesia through Strategic Research Grant 2018.

\section{References}

1. W. Partono, B. Pardoyo, I.D. Atmanto, L. Azizah, R.D. Chintami, AIP Conf. Proceedings 1903, 020008 (2017)

2. W. Partono, M. Irsyam, S.P.R. Wardani, MATEC Web of Conf. 101, 05010 (2017)

3. W. Partono, S.P.R. Wardani, M. Irsyam, S. Maarif, Jurnal Teknologi 78 : 8-5, 31-38 (2016)

4. Standar Nasional Indonesia, Tata Cara Perencanaan Struktur Bangunan Gedung dan Non Gedung (Indonesian National Standard, Seismic Code for Building and Other Structures Design), SNI-03-1726-2012 (2012)

5. Y. Osaki, R. Iwasaki, Soil and Foundations, JSSMFE. 13, 59-73 (1973)

6. Y. Ohta, N. Goto, Earthq. Eng. Struct. Dyn., 6, 167-187 (1978)

7. T. Imai, K. Tonouchi, Proc. Second Eur. Symp. Penetration Testing, Amsterdam, The Netherlands, 67-72 (1982)

8. W. Partono, S.P.R. Wardani, M. Irsyam, S. Maarif, Jurnal Teknologi 77 : 11, 99-107 (2015)

9. Pusat Studi Gempa Nasional, Peta Sumber dan Bahaya Gempa Indonesia Tahun 2017, Pusat Penelitian Perumahan dan Pemukiman, Kementerian Pekerjaan Umum dan Perumahan Rakyat (National Center for Earthquake Studies, Indonesian Seismic Sources and Seismic Hazard Maps 2017, Center for Research and Development of Housing and Resettlement, Ministry of Public Works and Human Resettlements), ISBN 978-602-5489-01-3 (2017)

10. N.A. Abrahamson, Non Stationary Spectral Matching Program RSPMATCH $>P G \& E$, Internal Report (1998)

11. W.D. Iwan, J. Appl. Mech., ASME, 34, 612-617 (1967)

12. Z. Mroz, J. Mech. Phys. Solids, 15, 163-175 (1967)

13. J.P. Bardet, T. Tobita, NERA A Computer Program for Nonlinear Earthquake Site Response Analysis of Layered Soil Deposits, Department of Civil Engineering University of Southern California (2001) 